Omni-Akuatika 12 (2): 125 - 129, 2016
ISSN: 1858-3873 print / 2476-9347 online
Research Article

\title{
The Sea Urchin (Echinoidea) from Panjang Island Water, Bangka Belitung Province
}

\author{
Siti Aisyah Lubis ${ }^{{ }^{*}}$, Rofiza Yolanda ${ }^{1}$, Arief Anthonius Purnama ${ }^{1}$, Ria Karno ${ }^{1}$ \\ ${ }^{1}$ Biology Education Study Programme, Faculty of Teacher Training and Education, University of Pasir \\ Pengaraian, Jl. Tuanku Tambusai Km. 10, Desa Rambah, Rambah Hilir Sub-District, Rokan Hulu District 28557, \\ Riau Province, Indonesia \\ ${ }^{*}$ Corresponding author: sitiaisyahlubis7@gmail.com \\ Received 25 June 2016; Accepted 15 October 2016; Available online 30 November 2016
}

\begin{abstract}
This study has been conducted from May to July 2016 in Panjang island, Bangka Tengah District, Bangka Belitung Province. The aims of this study was to evaluate the species of sea urchins by using survey method at four sites. Sampling was done by using a square transect of $50 \times 50 \mathrm{~m}^{2}$. A total of 868 individuals of sea urchin belonging to 2 species were recorded in this study, namely Diadema setosum and Echinothrix calamaris. D. setosum was the most abundant in individual number (828 individuals) meanwhile E. calamaris only 40 individuals.
\end{abstract}

Keywords: Diadema setosum, Echi nothrix calamaris, reef flat

\section{Introduction}

Echinodermata is an ancient and very successful phylum of invertebrates with around 6,000 living members (Suwignyo et al., 2005). In particular, the shallow-water echinoderm fauna of the Indo-West Pacific is generally considered to be very rich, one of them is the sea urchin. There were probably 84 species of sea urchin, which belonging to 31 families and 48 genera from Indonesia (Clark and Rowe, 1971). Generally, distribution of the sea urchin species varies from the intertidal zone down to a depth of a hundred meters or more (Jeng, 1998) and inhabit coral reef and sea grass bed and shelter in crevices on reefs (Aziz, 1994; Yusron and Susetiono, 2010; Supono and Arbi, 2012).

This organisms also play important role in marine ecosystem, e.g. algae feeder (controlling blooming of algae), deposit feeder, fish protector (Aziz, 1987; Moore, 2006; Takabayasi et al., 2007) and also as a pray for predators, such as crabs, coral fishes, sea otter, eels, birds, etc. (Shirley, 1982; Birkeland, 1989). And for human being, the gonad of the sea urchin have been widely consumed by human for food (Aziz, 1993; Radjab, 1998); they also can be used for environmental toxicology test (Lasut et al., 2002; Takei et al., 2014). Several species, Asthenosoma, Diadema setosum, Salmacis sphaeroides, Toxopneustes pileolus and Tripneustes gratilla could produce peditoxin, a bioactive material for pharmacology (Rahman et al., 2014). In Philippines they also consumed as energy drink (sea food flavored tea) which contain mineral, calcium, iodine, zinc and potassium (Estacio, 2010). According to Shankarlal et al. (2011) the sea urchin also can be used as antimicrobial and antioxidant. Due to the abundance and the importance of the sea urchin species in the world many researchers have studied about this organisms.

Study on the sea urchin species from Indonesia have been reported by several researchers; for examples Yusron (2003) reported that 5 species of sea urchin were found from Tapak Tuan water, Aceh; Yusron and Susetiono (2005) reported that 4 species of sea urchin were found from Tanjung Merah water, Sulawesi Utara; Yusron (2006) reported that 4 species of sea urchin were found from Takofi beach, Moti islan, Maluku Utara; Yusron and Susetiono (2010) reported that 7 species of sea urchin were found from Ternate water, Maluku Utara; Supono and Arbi (2012) reported that 5 species of sea urchin were found from Pari island, Kepulauan Seribu; Rompis et al. (2013) reported that 4 species of sea urchin were found from Meras beach, Sulawesi Utara; Yusron (2013) reported that 5 species of sea urchin were found from Lombok island, Nusa Tenggara Barat; Zakaria (2013) reported that 7 species of sea urchin were found on 3 islands from Sumatera Barat; Setyastuti (2014) reported that 7 species of sea urchin were found from Nusa Laut island, Maluku; Tuapattinaja et al. (2014) reported that 4 species of sea urchin were found from Tanjung Tira, Ambon. However, no study has reported 
on the sea urchin species in Panjang island, Bangka Tengah Sub-District, Bangka Belitung Province.

Panjang island is located in Bangka Tengah District, Bangka Belitung Province. This island has several habitat for sea urchin, such as coral reef and seagrass. However, the increasing activity of the fisherman on the shallow water and reef zone in this island may have an impact on the sea urchin in this water. Therefore to provide data on the sea urchin, a field study was conducted in Panjang island water, Bangka Tengah District, Bangka Belitung Province. The aim of this study was to determine the species diversity of sea urchin from Panjang island water.

\section{Material and Methods}

\section{Study area}

This study was conducted from May to July 2016 in Panjang island water, Bangka Tengah District, Bangka Belitung Province. Four sampling sites were determine based on the island position (east, west, north and south) (Figure 1).

\section{Sea urchin sampling and data analysis}

Samples were collected by swimming and snorkeling on the water. The underwater photograph of live specimen was documented and the samples was taken by hand-picking technique on the $50 \times 50 \mathrm{~m}^{2}$ square transect which lied from the intertidal zone to the depth zone by following the reef flat. The samples were sorted and preserved in $70 \%$ alcohol. Some environmental parameters were measured at each stations. Temperature was measured by mercury thermometer, water acidity $(\mathrm{pH})$ was measured by MERCK universal indicator paper (scale 0-14), brightness was measured with sacchi disc, depth was measured by stick meter and salinity was measured using TI-SAT100 (A) TRANS INSTRUMENTS Hand Refractometer. Identification of the specimen was done based on Clark and Rowe (1971), Jeng (1998) and Yusron (2006). The data was analyzed by presenting the result on figures and table and also discussed based on the environmental measurements.

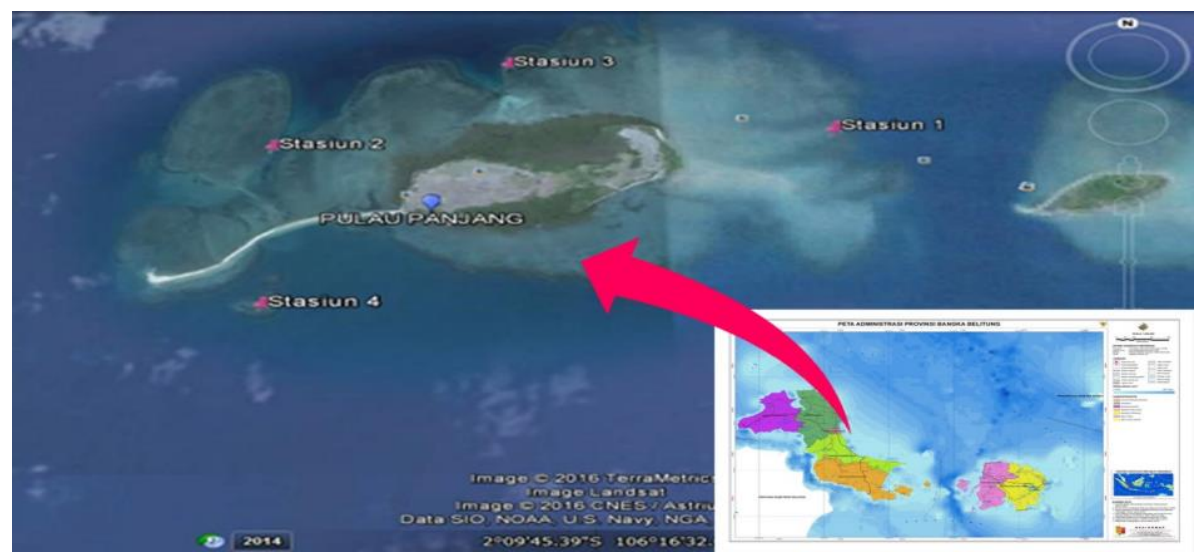

Figure 1. Study site and sampling stations in Panjang island water, Bangka Tengah District, Bangka Belitung Province

Table 1. Study site of the sea urchin and its characteristics.

\begin{tabular}{|c|c|c|}
\hline No. & Sites & Characteristics \\
\hline 1. & $\begin{array}{c}\text { Station } 1 \\
02^{0} 09^{\prime} 5.17^{\prime \prime} \mathrm{N} \\
106^{0} 17^{\prime} 8.73^{\prime \prime} \mathrm{E}\end{array}$ & $\begin{array}{l}\text { Shallow water, sandy substrate with coral reef and sea grass. } \\
\text { Temperature between } 30-31{ }^{\circ} \mathrm{C}, \mathrm{pH} 8 \text {, brightness } 4 \text { meter, depth } 4 \\
\text { meter and salinity } 34 \% 00\end{array}$ \\
\hline 2. & $\begin{array}{l}\text { Station } 2 \\
02^{0} 09^{\prime} 9.73 \mathrm{~N} \\
106^{0} 15^{\prime} 42.18^{\prime \prime} \mathrm{E}\end{array}$ & $\begin{array}{l}\text { Shallow water, sandy substrate with coral reef and sea grass. } \\
\text { Temperature between } 29-30{ }^{\circ} \mathrm{C}, \mathrm{pH} 8 \text {, brightness } 3.5 \text { meter, depth } 3.5 \\
\text { meter and salinity } 34 \% 00\end{array}$ \\
\hline 3. & $\begin{array}{l}\text { Station } 3 \\
02^{0} 08^{\prime} 43.98 " \mathrm{~N} \\
106^{0} 16^{\prime} 18.06^{\prime \prime} \mathrm{E}\end{array}$ & $\begin{array}{l}\text { Shallow water, sandy substrate with coral reef and sea grass. } \\
\text { Temperature between } 28-30{ }^{\circ} \mathrm{C}, \mathrm{pH} 8 \text {, brightness } 4 \text { meter, depth } 4 \\
\text { meter and salinity } 34 \% 00\end{array}$ \\
\hline 4. & $\begin{array}{c}\text { Station } 4 \\
02^{0} 09^{\prime} 52.69^{\prime \prime} \mathrm{N} \\
106^{0} 15^{\prime} 43.61^{\prime \prime} \mathrm{E}\end{array}$ & $\begin{array}{l}\text { Shallow water, sandy substrate with coral reef and sea grass. } \\
\text { Temperature between } 28-30{ }^{0} \mathrm{C}, \mathrm{pH} 8 \text {, brightness } 4 \text { meter, depth } 4 \\
\text { meter and salinity } 34 \% 00\end{array}$ \\
\hline
\end{tabular}




\section{Results and Discussion}

\section{Species composition}

A total 868 individuals of sea urchin belonging to 2 species were recorded during the study, namely Diadema setosum dan Echinothrix calamaris (Figure 2). D. setosum has higher number of individuals with total 828 individuals, meanwhile E. calamaris with 40

The abundance individual number of $D$. setosum due to the habitat and also the suitable of environment condition which support the live of this species, e.g. sandy substrate, coral reef and sea grass. According to Aziz (1993) D. setosum commonly live in coral reef ecosystem and sea grass by grouping. They also hide in holes or crevasses of reef (Thamrin et al., 2011). Meanwhile the low number of individual from $E$. calamaris in individuals. The abundance of $D$. setosum from every sites were 158 individuals (station 1), 243 individuals (station 2), 219 individuals (station 3) and 208 individuals (station 4) and the abundance of $E$. calamaris were 1 individual (station 1), 14 individual (station 2), 0 individual (station 3 ) and 25 individual (station 4) (Tabel 2).

this study due to their habit which live in solitary and their distribution at the edge of reef which may affect the amount of this species. According to Takabayasi et al. (2007) the sea urchin ( $E$. calamaris) always appear in mixing group and use coral reef and edge of the reef as its habitat. This species always lacking in individual number compared to $D$. setosum, and some of this species are solitary organism.
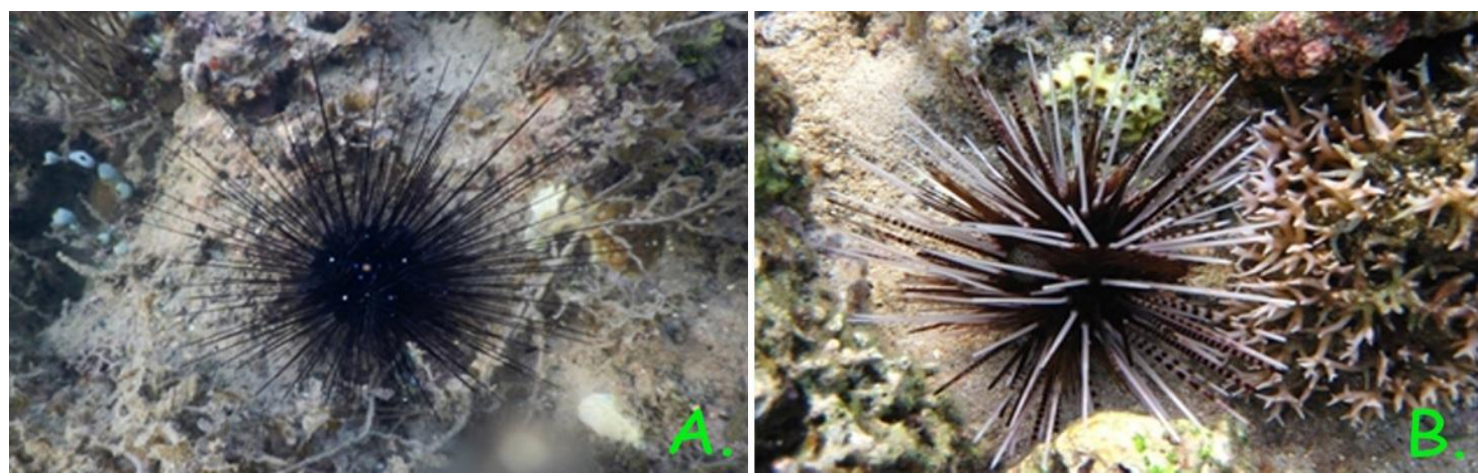

Figure 2. The sea urchin species from Panjang island water, Bangka Tengah District, Bangka Belitung Province. (A) Diadema setosum, (B) Echinothrix calamaris.

Table 2. List of species and abundance of the sea urchin at sampling stations in Panjang island water.

\begin{tabular}{|c|c|c|c|c|c|c|c|}
\hline \multirow{2}{*}{ No. } & \multirow{2}{*}{ Spesies } & \multirow{2}{*}{$\begin{array}{l}\text { Vern. } \\
\text { Name }\end{array}$} & \multicolumn{4}{|c|}{ Station } & \multirow[b]{2}{*}{ Total } \\
\hline & & & 1 & 2 & 3 & 4 & \\
\hline 1. & Diadema setosum (Leske, 1778) & Janik & 158 & 243 & 219 & 208 & 828 \\
\hline 2. & Echinothrix calamaris (Pallas, 1774) & Janik & 1 & 14 & - & 25 & 40 \\
\hline & Total & & 159 & 275 & 219 & 233 & 868 \\
\hline
\end{tabular}

\section{Environmental measurements}

Several environmental parameter or abiotic factors such as temperature, water acid $(\mathrm{pH})$, salinity, brightness and depth also determine the living of the sea urchin. Based on Table 1 the measurements of several environment factors e.g. temperature between $28-31^{\circ} \mathrm{C}$, water acid ( $\left.\mathrm{pH} 8\right)$, brightness 4 meter, depth 3.5-4 meter and salinity 34-35\% are in a good criteria for the living of the sea urchin. According to Zakaria (2013) and Budiman et al. (2014) temperature between $28-32{ }^{\circ} \mathrm{C}$ is good for sea urchin occurrence in tropical zone and most of the aquatic fauna live on water acid $(\mathrm{pH})$ 7-8.5 and they are very sensitive with the differences of the water acid $(\mathrm{pH})$, including the sea urchin. In addition, the regulation of the Ministry of Living Environment of Republic Indonesia Affairs No. 51, 2004 stated that the suitable water acid $(\mathrm{pH})$ for the sea urchin are $\mathrm{pH} 7-8,5$. For brightness between 3-5 meter is a good criteria to support the development of the sea urchin. According to Aziz (1994) the sea urchin can be found on the shore until 10 meter depth. In addition, based on Ridder et al. (1990) the brightness of sea water between 0- 
20 meter is suitable for the sea urchin. For salinity, Hutauruk (2009) and Zakaria reported that the salinity between $34-35 \%$ is normal and good for the sea urchin. Overall, the habitat and the environment condition in Panjang island is good for the living of the sea urchin.

\section{Conclusion}

The sea urchin that was found in Panjang island, Bangka Tengah District, Bangka Belitung Province about 868 individual belonging 2 species, namely Diadema setosum and Echinothrix calamaris. The species $D$. setosum is very abundant with 828 individuals while $E$. calamaris about 40 individuals. The environment parameter indicate that the condition of the water is suitable for the sea urchin.

\section{References}

Aziz, A. 1987. Makanan dan cara makan berbagai jenis bulu babi. Oseana 12 (4): 91-100.

Aziz, A. 1993. Beberapa catatan tentang perikanan bulu babi. Oseana 18 (2): 6575.

Aziz, A. 1994. Tingkah laku bulu babi di padang lamun. Oseana 19 (4): 35-43.

Birkeland, C. 1989. The influence of echinoderm on coral reef communities. In: Jangoux, M. and Lawrence, J.M. (Eds.), Echinoderms Studies. Vol. 3. Balkema, Rotterdam, Netherland.

Budiman, C.C., Katili, D.Y., Langoy, M.L.D., Maabat, P.V. 2014. Keanekaragaman Echinodermata di pantai Basaan Satu Kecamatan Ratatotok Sulawesi Utara. Jurnal Mipa Unsrat Online 3 (2): 97-101.

Clark, A.M., Rowe, F.W.E. 1971. Monograph of Shallow-Water Indo-West Pacific Echinoderms. Trustees of the British Museum (Natural History), London, 238 pp.

Estacio, R.M. 2010. Sea food flavored-tea product development. E-International

Setyastuti, A. 2014. Ekinodermata pulau Nusa Laut (Maluku, Indonesia). Oseanologi dan Limnologi di Indonesia 40 (1) : 1-10.

Shankarlal, S., Prabu, K., Natarajan, E. 2011. Antimicrobial and antioxidant activity of purple sea urchin shell (Salmacis virgilata L. Agassiz and Desor 1846). American-Eurasian Journal of Scientific Research 6 (3): 178-181.
Scientific Research Journal 2 (3): 172181.

Hutahuruk, E.L. 2009. Studi keanekaragaman Echinodermata di perairan pulau Rubiah Nanggroe Aceh Darussalam. Skripsi, Universitas Sumatera Utara Medan. Medan.

Jeng, M.S. 1998. Shallow-water echinoderms of Taiping island in the South China Sea. Zoological Studies 37 (2): 137-153.

Lasut, M.T., Sumilat, D.A., Arbie, D.T. 2002. Pengaruh konsentrasi sublethal diazinon 60 ec terhadap perkembangan awal embrio bulu babi Echinometra mathaei. Ekoton 2 (1): 17-24.

Menteri Lingkungan Hidup. 2004. Baku Mutu Air Laut. Keputusan Menteri Lingkungan Hidup Nomor 51.

Moore, J. 2006. An introduction to the Invertebrates. Second Edition. Cambridge University Press, Cambridge, UK. 319 pp.

Radjab, A.W. 2001. Sebaran dan kepadatan bulu babi di perairan Kepulauan Paidado, Biak, Irian Jaya. Prosiding seminar kelautan III-ISOI. Jakarta.

Rahman, M.A., Arshad, A., Yusoff, F.Md. 2014. Sea urchins (Echinodermata: Echinoidea): their biology, culture dnd bioactive compounds. Proceeding of the International Conference on Agricultural, Ecological and Medical Sciences (AEMS-2014) July 3-4 2014 London (United Kingdom). 39-48 pp.

Ridder, C.D., Dubois, P., Lahaye, M.-C., Jangoux, M. 1990. Echinoderm research. Procedding of the Second European Conference on Echinoderms, Brussels, Belgium September 18-21 1989, A.A. Balkema, Rotterdam, 343 pp.

Rompis, B.R., Langoy, M.L.D., Katili, D.Y., Papu, A. 2013. Diversitas echinodermata di pantai Meras Kecamatan Bunaken Sulawesi Utara. Jurnal Bioslogos 3 (1): 26-30.

Shirley, T.C. 1982. The importance of echinoderm in the diet of fishes of a sublittoral rock reef In: Chapman and Tunel, J.W. (eds.), South Texas Fauna. Caesar Kleberg Wild Life Researches Institute: 49-55.

Supono, Arbi, U.Y. 2012. Kelimpahan dan keragaman Echinodermata di pulau Pari, Kepulauan Seribu. Jurnal IImu 
dan Teknologi Kelautan Tropis 4 (1): 114-120.

Suwignyo, S., Widigdo, B., Wardianto, Y., Kristanti, M. 2005. Avertebrata air jilid 2. Penebar Swadaya, Jakarta.

Takabayasi, M., Jessop, H., Demaentanon, M. 2007. Sea urchin herbivory in hawaiian shallow water ecosystem. HCRI Project Report: 1-7.

Takei, M., Nakagawa, H., Kimura, A., Endo, K. 1991. A toxic substance from the sea urchin Toxopneustes pileolus induces histamine release from rat peritoneal mast cells. Inflammation Research 32 (3-4): 224-228.

Thamrin, Y.J., Setiawan, Siregar, S.H. 2011. Analisis kepadatan bulu babi Diadema setosum pada kondisi terumbu karang berbeda di desa Mapur Kepulauan Riau. Jurnal Ilmu Lingkungan 5 (1): 45-53.

Tuappatinaja, M.A., Pattikawa, J.A., Natan, Y. 2014. Community structure of echinoderm at Tanjung Tiram, Inner Ambon Bay, Indonesia. AACL Bioflux 7 (5): 351-356.

Yusron, E. 2003. Beberapa catatan fauna ekhinodermata dari perairan Tapak
Tuan, Aceh Selatan Nangroe Aceh Darussalam. Makara Sains 7 (3): 97104.

Yusron, E. 2006. Biodiversitas ekhinodermata di perairan pantai Takofi, Pulau MotiMaluku Utara. Makara Sains 10 (1): 4146.

Yusron, E. 2013. Biodiversitas fauna ekhinodermata (Holothuroidea, Echinoidea, Asteroidea dan Ophiuroidea) di perairan pulau Lombok, Nusa Tenggara Barat. Zoo Indonesia 22 (1): $1-10$

Yusron, E., Susetiono. 2005. Fauna ekhinodermata dari perairan Tanjung Merah Selat Lembeh-Sulawesi Utara. Makara Sains 9 (2) : 60-65.

Yusron, E., Susetiono. 2010. Diversitas fauna ekhinodermata di perairan TernateMaluku Utara. Oseanologi dan Limnology di Indonesia 36 (3): 293307.

Zakaria, I.J. 2013. Komunitas bulu babi (Echinoidea) di pulau Cingkuak, pulau Sikuai dan pulau Setan Sumatera Barat. Prosiding SEMIRATA FMIPA Universitas Lampung. Lampung. 381$387 \mathrm{pp}$. 